\title{
Response of bananas (Musa acuminata, AAA) to magnesium fertilization in an Ultisol ${ }^{1,2}$
}

\author{
Héber Irizarry, ${ }^{3}$ Edmundo Rivera ${ }^{4}$ and José A. Rodriguez ${ }^{3}$
}

\begin{abstract}
An experiment was conducted to determine the effect of rates and sources of $\mathrm{Mg}$ on yield and leaf composition of the Grand Nain banana, grown on a Corazal clay during a 3-year period. The $\mathrm{Mg}$ rates tested were $0,56,112,168,224$ and $448 \mathrm{~kg} / \mathrm{ha} /$ year. The source of $\mathrm{Mg}$ for treatments 2,3 and 4 was magnesium sulfate (Epsom salt), and for treatments 5 and 6 dolomitic limestone the first year and commercial magnesium oxide (Fert-O-Mag) in subsequent years. An optimum yield response of $8.9 \mathrm{t} / \mathrm{hal}$ year of bananas was obtained with annual applications of about 275 $\mathrm{kg} / \mathrm{ha}$ of $\mathrm{Mg}$ from dolomitic limestone the first year and commercial magnesium oxide in subsequent years. Considering magnesium sulfate as the source of $\mathrm{Mg}$, and estimating the cost of materials and local farm gate banana prices, the optimum economic response is obtained with applications of 112 to $168 \mathrm{~kg} / \mathrm{ha} /$ year of $\mathrm{Mg}$. This represents a yield increase of 5.8 to $7.7 \mathrm{t} / \mathrm{ha}$ /year of fruits over the $\mathrm{O} \mathrm{Mg}$ treatment. Magnesium concentration in the third youngest banana leaf averaged $0.30 \%$ in plants that received 224 and $448 \mathrm{~kg} / \mathrm{ha}$ of $\mathrm{Mg}$ from dolomite in the plant-crop.
\end{abstract}

\section{RESUMEN}

Respuesta del guineo (Musa acuminata, AAA) al abonamiento con magnesio en un suelo Ultisol

Se llevó cabo un experimento para determinar el efecto de la fertilización con $\mathrm{Mg}$ sobre el rendimiento y contenido foliar del guineo Grand Nain sembrado en un suelo rojo durante 3 años sucesivos. Las cantidades de $\mathbf{M g}$ aplicadas fueron: $0,56,112,168,224$, y $448 \mathrm{~kg}$./ha./año. La fuente de $\mathrm{Mg}$ para los tratamientos 2, 3 y 4 fue sulfato de magnesio. Los tratamientos 5 y 6 recibieron dolomita calcítica el primer año y óxido de magnesio comercial en años subsiguientes. Se obtuvo un rendimiento óptimo de 8.9 $\mathrm{Tm}$./ha./año de frutas vendibles con aplicaciones de aproximadamente $\mathbf{2 7 5}$ kg./ha./año de $\mathrm{Mg}$ proveniente de dolomita en la plantilla y óxido de magnesio de los retoños. Considerando el sulfato de magnesio como la fuente de $\mathrm{Mg}$ y estimando el costo de materiales y el precio del guineo a nivel de la finca, la respuesta económicamente óptima se obfuvo con aplicaciones de 112 a $168 \mathrm{~kg}$./ha./año de $\mathrm{Mg}$. Estas aplicaciones representan un aumento en rendimiento de 5.8 a $7.7 \mathrm{Tm}$./ha./año de frutas sobre el

'Manuscript submitted to Editorial Board 19 January 1990.

${ }^{2}$ This paper covers work carried out cooperatively between the Agricultural Research Service-USDA, and the Agricultural Experiment Station, University of Puerto Rico (AES-UPR) Rio Piedras, P.R.

${ }^{3}$ Research Horticulturist, Agricultural Research Service, USDA, Mayagüez, P.R.

"Agronomist, Agricultural Research Service, USDA, Mayagüez, P.R.

'Associate Agronomist, Department of Agronomy and Soils, Agricultural Experiment Station, Corozal, P.R. 
tratamiento de $\mathrm{O} \mathrm{Mg}$. El contenido de $\mathrm{Mg}$ en la tercera hoja más joven del guineo arrojó un promedio de $0.30 \%$ en las plantas que recibieron 224 y $448 \mathrm{~kg} . / \mathrm{ha}$. del nutrimento proveniente de dolomita en la plantilla.

\section{INTRODUCTION}

There are about 240,000 hectares of red-acid Ultisols and Oxisols in Puerto Rico with limited uses, mainly located in the humid mountain region (14). These soils are characterized by the presence of toxic levels of $\mathrm{Al}$ or $\mathrm{Mn}$ and a low natural fertility, particularly, $\mathrm{P}, \mathrm{K}$, and $\mathrm{Mg}(1,4$, 11). In spite of these constraints, however, most of these soils have excellent physical properties. Those with moderate topography, when properly managed, can produce high yields, especially when planted with acid tolerant crops such as plantains and bananas (9).

Previous research has shown that plantains grown on Ultisols respond to $\mathrm{Mg}$ fertilization. Caro-Costas et al. (2), Hernández-Medina and Lugo-López (5), and Samuels et al. (10), reported significant yield increases with applications of 44 to $122 \mathrm{~kg} / \mathrm{ha}$ of $\mathrm{Mg}$ when this crop was planted in three typical Ultisols. Irizarry et al. (7) determined nutrient uptake in the Grand Nain banana grown on a Corozal clay and reported a $\mathrm{Mg}$ uptake of $54 \mathrm{~kg} / \mathrm{ha} / \mathrm{crop}$. In long-term field experiments with Pangola grass, Vicente-Chandler et al. (13) found that the Mg-supplying power of six major upland soils of Puerto Rico was about $35 \mathrm{~kg} / \mathrm{ha} /$ year.

This paper reports the results obtained with applications of six rates and three sources of $\mathrm{Mg}$ to intensively managed bananas gxown on a red-acid soil.

\section{MATERIALS AND METHODS}

An experiment was performed at the AES-UPR Corozal Substation from September 1984 through August 1987. The substation is located in the humid north-central uplands, at an elevation of about $200 \mathrm{~m}$. Throughout the experiment, mean monthly rainfall was $192 \mathrm{~mm}$ and pan evaporation $120 \mathrm{~mm}$. The wettest months were April, May and September through November, averaging $302 \mathrm{~mm}$. The driest were January, February, June and July, during which time pan evaporation value exceeded rainfall. Average monthly minimum and maximum temperatures were $19.5^{\circ}$ and $29.8^{\circ} \mathrm{C}$, respectively with variations of plus or minus $2.4^{\circ}$ C.

The soil is a Corozal clay (Aquic Tropudults-clayey, mixed, isohyperthermic). The top $30 \mathrm{~cm}$ of soil contained $7.3 \mathrm{mg} / \mathrm{kg}$ of available P (Bray method 2) and $0.47,1.7$ and $7.8 \mathrm{cmol}(+) / \mathrm{kg}$ of exchangeable $\mathrm{K}, \mathrm{Mg}$ and $\mathrm{Ca}$, respectively. The soil was plowed and harrowed twice to a $25-\mathrm{cm}$ depth and limestone applied at the rate of 5.6 t/ha to bring the soil $\mathrm{pH}$ to about 5.2 .

Grand Nain banana suckers weighing about $2 \mathrm{~kg}$ were planted in rows spaced at 1.8 by $1.8 \mathrm{~m}$, about 3,000 plants/ha. 
Six Mg levels, 0, 56, 112, 168, 224 and $448 \mathrm{~kg} / \mathrm{ha} /$ year, were tested in a randomized complete block design with six replications of nine plants per plot. Ditches about 30 -cm deep were dug around each plot to prevent cross feeding. The source of $\mathrm{Mg}$ for treatments 2, 3 and 4 was magnesium sulfate (Epsom salt, 9.8\% Mg); for treatments 5 and 6, dolomitic limestone $(10.4 \% \mathrm{Mg}$ ) the first year, and commercial magnesium oxide (Fert$\mathrm{O}-\mathrm{Mag}^{6}, 51.5 \% \mathrm{Mg}$ ) in subsequent years. The dolomite was incorporated into the soil before planting. The magnesium sulfate and oxide formulations were divided into three equal quantities yearly and applied between regular complete fertilizer applications. The plant-crop was fertilized with $3,000 \mathrm{~kg} / \mathrm{ha}$ of a $10-5-20\left(\mathrm{~N}, \mathrm{P}_{2} \mathrm{O}_{5}, \mathrm{~K}_{2} \mathrm{O}\right)$ fertilizer supplemented with $25.4 \mathrm{~kg} / \mathrm{t}$ of a fritted minor element mixture. The fertilizer was divided into equal parts and applied at 2, 5, 8 and 11 months after planting. Thereafter, the ratoon plants were fertilized at the rate of $750 \mathrm{~kg} / \mathrm{ha}$ every 3 months.

Yellow Sigatoka (Mycosphaerella musicola), nematodes, and the corm weevil (Cosmopolites sordidus) were controlled in accordance with published recommendations (6).

Weed growth was suppressed with postemergence applications of glyphosate (Round-up) at the rate of $1.5 \% \mathrm{v} / \mathrm{v}$. A desuckering program was implemented 5 months after planting to maintain in each stump the mother plant plus two suckers, the latter representing the "daughter" and "grand-daughter" plants.

Leaf samples for chemical analyses were taken from 7- and 10-monthold plants in the plant-crop, and from the 1st and 2nd ratoon crops 17 and 27 months after planting, respectively. Middle strips of the third youngest leaf lamina of six plants in each plot were composited, ovendried at $70^{\circ} \mathrm{C}$, ground, passed through a 20 -mesh screen and analyzed for N, P, K, Ca, Mg and Mn. Nitrogen was determined by the micro-KjeJdahl method, $\mathrm{P}$ colorimetrically, and the other nutrients by atomic absorption after extraction with the Drying-Ashing method (3).

The lowest hand and the male flower bud were removed from the immature bunches soon after bunch shooting. The mature bunches were harvested and weighed when the fruits were $3 / 4$ full, about 115 days after bunch shooting. Marketable fruit weight was determined by subtracting $17 \%$ bunch weight from gross weight in accordance with Irizarry et al. (8).

After the last harvest, the soil in the experimental plots was sampled to determine residual $\mathrm{Mg}$. Six samples from each plot were taken at a soil depth of $30 \mathrm{~cm}$ and $45 \mathrm{~cm}$ away from the base of the plants.

\footnotetext{
${ }^{6}$ Trade names in this publication are used only to provide specific information. Mention of a trade name does not constitute a warranty of equipment or materials by the Agricultural Experiment Station of the University of Puerto Rico or the USDA, ARS, nor is this mention a statement of preference over other equipment or materials.
} 


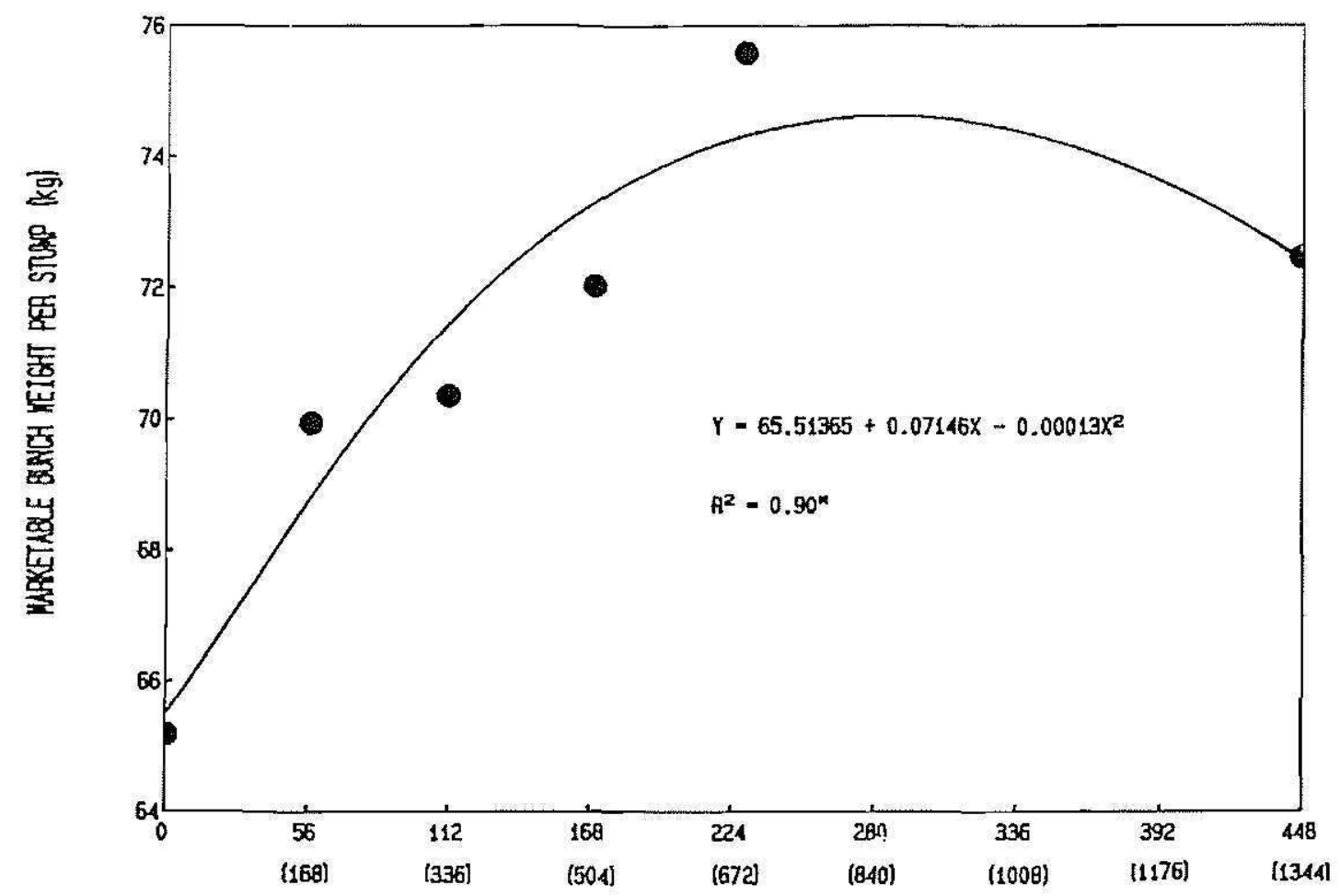

AWUK ANO TOTN PATES OF Hg RPQLIEI $\mathrm{Kg} / \mathrm{ha}$ )

FJG. 1.-Relationship between levels of $\mathrm{Mg}$ applied and total marketable bunch weight after a 3-year growing period.

\section{RESULTS AND DISCUSSION}

Intensively managed banana grown on a Corozal clay (Ultisol) responded to $\mathrm{Mg}$ fertilization during a 3-year period (fig. 1). The regression analysis for rates of $\mathrm{Mg}$ applied and bunch weight showed that optimum yield ( $74.4 \mathrm{~kg}$ of marketable fruits per stump) was obtained with the incorporation of about $275 \mathrm{~kg} / \mathrm{ha}$ of $\mathrm{Mg}$ from dolomite the first year followed by a similar rate from commercial magnesium oxide in subsequent years. This response represents a yield increase of 8.9 t/ha of bananas over the $0-\mathrm{Mg}$ treatment.

With magnesium sulfate as the source of $\mathrm{Mg}$, and estimating the cost of materials at $48 \phi / \mathrm{kg}$ and local farm gate banana prices at $25 \% / \mathrm{kg}$, the optimum economic application rate of $\mathrm{Mg}$ lies between 112 to $168 \mathrm{~kg} / \mathrm{ha}$ year. This treatment represents a yield increase of 5.8 and $7.7 \mathrm{t} / \mathrm{ha} / \mathrm{year}$, respectively, over the $0-\mathrm{Mg}$ treatment. In plantains grown on an Ultisol, Samuels et al. (10) reported a significant yield increase in the plant-crop with the application of up to $122 \mathrm{~kg} / \mathrm{ha}$ of $\mathrm{Mg}$ as magnesium sulfate. 


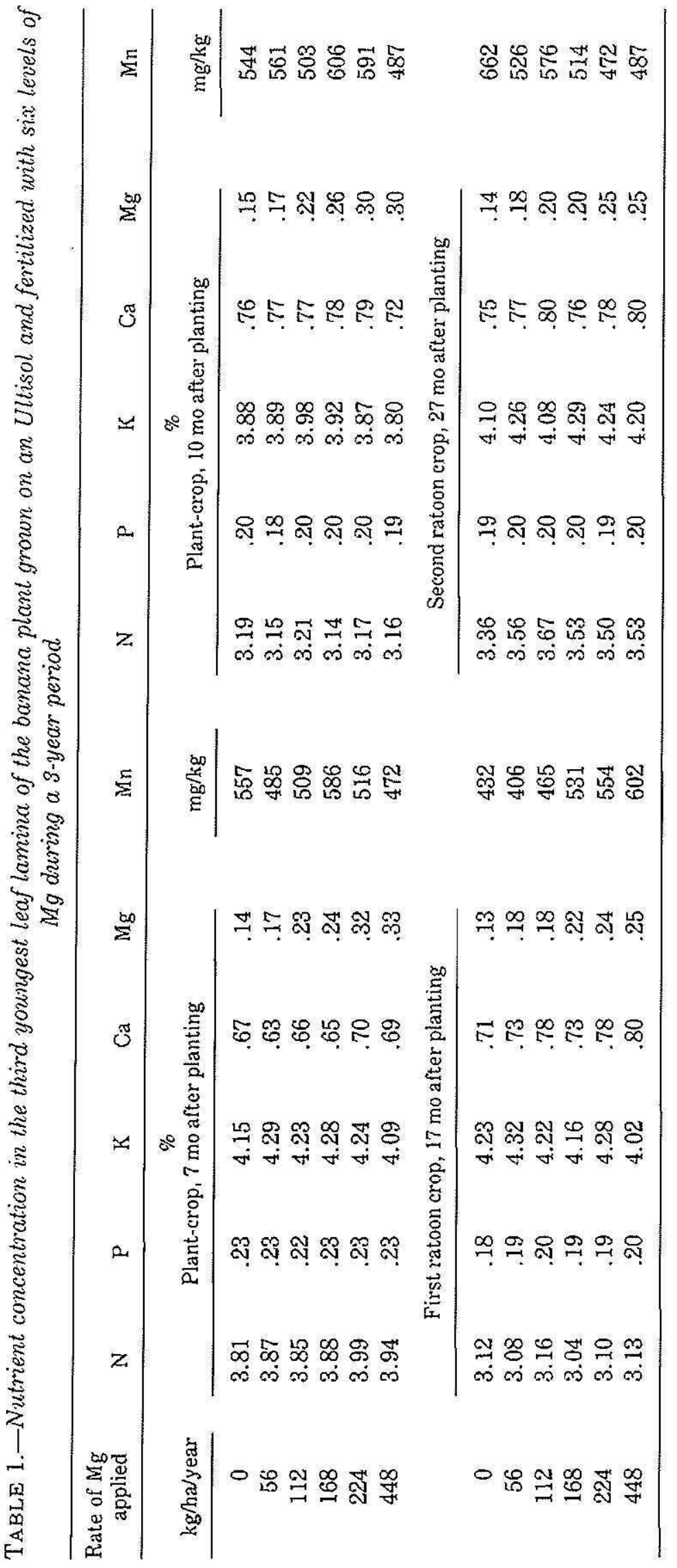




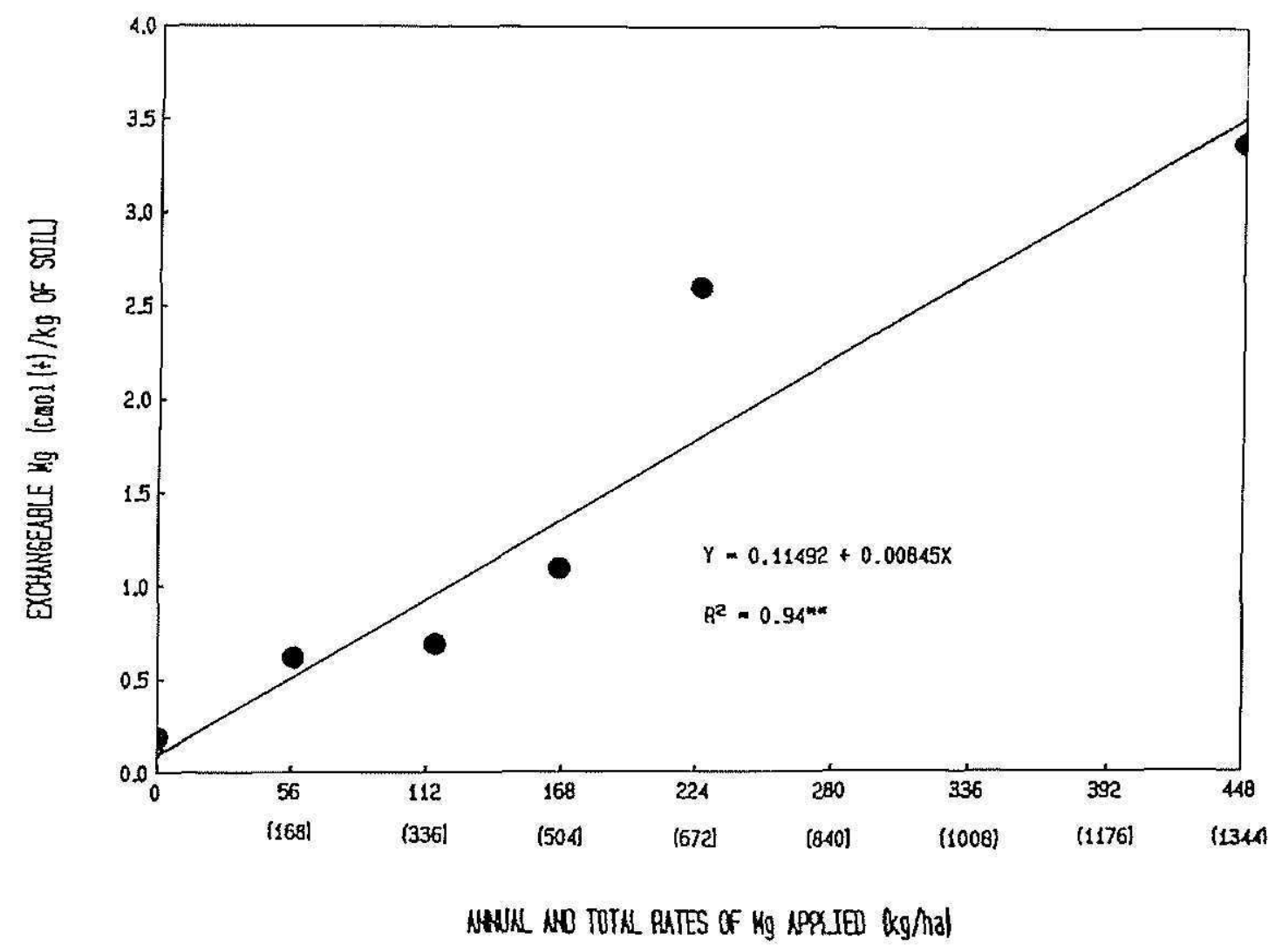

FIG. 2.-Relationship between levels of $\mathrm{Mg}$ applied and the exchangeable $\mathrm{Mg}$ in the soil after a 3-year growing period.

Magnesium concentration in the third youngest banana leaf increased in proportion to the rates of the nutrient applied (table 1). However, except for the 0.30 to $0.33 \% \mathrm{Mg}$ detected in plants that received 224 and $448 \mathrm{~kg} / \mathrm{ha}$ of $\mathrm{Mg}$ from dolomite in the plant-crop, other values were considered somewhat low. Irizarry et al. (7) reported $0.38 \% \mathrm{Mg}$ as the nearoptimum for well nourished bananas grown on an Ultisol. Soto (12) summarized other studies and reported a leaf concentration of 0.30 to $0.40 \%$ $\mathrm{Mg}$ for optimum banana growth. A concentration below $0.25 \%$ was considered critical.

At the termination of the experiment, residual exchangeable $\mathrm{Mg}$ in the soil was proportional to the amounts of the nutrient applied (fig. 2). However, only those plots that received the higher rates (224 and 448 $\mathrm{kg} / \mathrm{ha} /$ year) of $\mathrm{Mg}$ from combined applications of dolomite and commercial magnesium oxide surpassed the initial amount of $1.7 \mathrm{cmol}(+) / \mathrm{kg}$ of $\mathrm{Mg}$ detected in the soil at the beginning of the experiment.

Except for the highest $\mathrm{Mg}$ application rate of $448 \mathrm{~kg} / \mathrm{h} / \mathrm{year}$, bunch weight increased in direct proportion to the exchangeable $\mathrm{Mg}$ in the soil (fig. 3). 


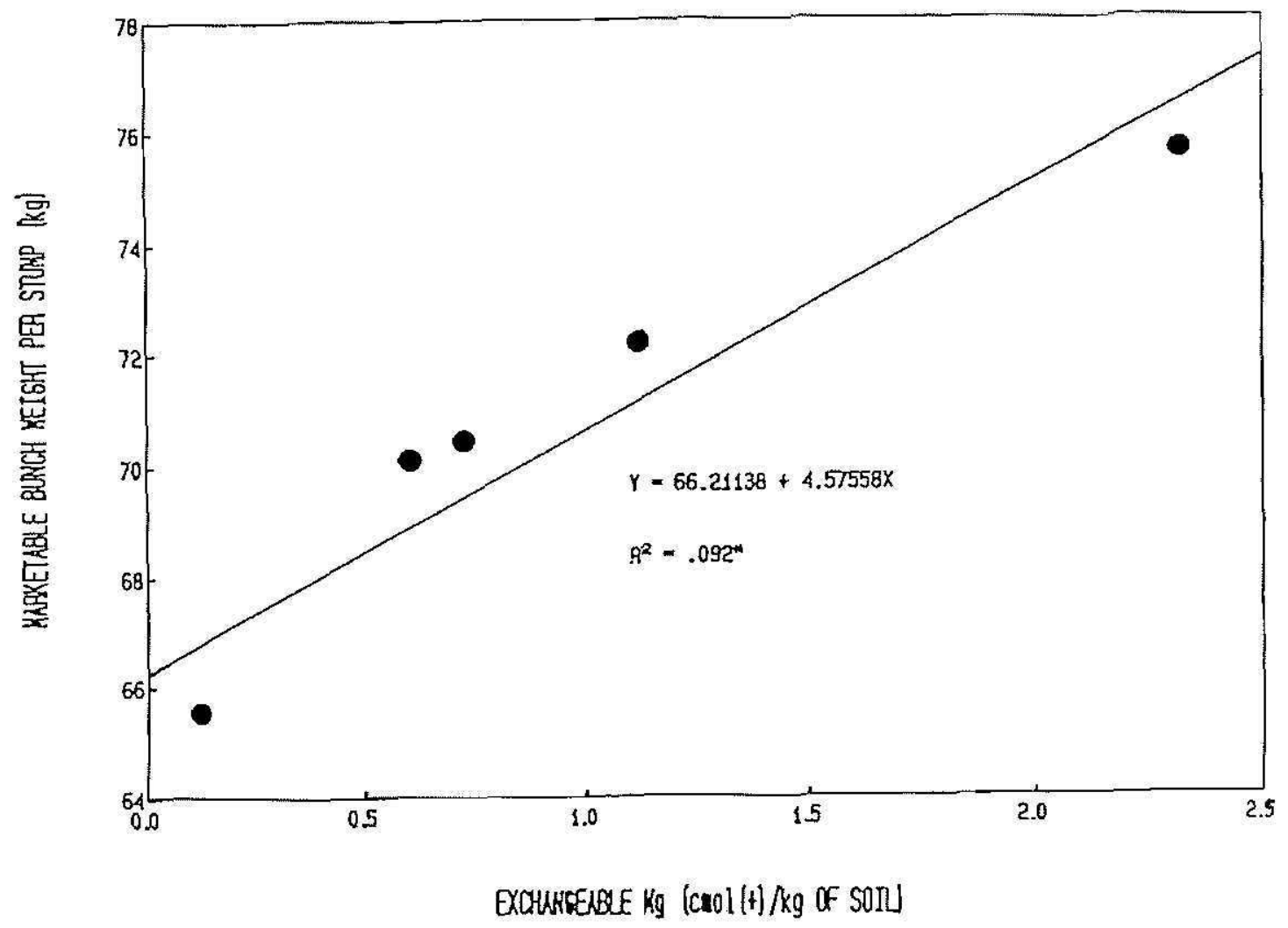

FIG. 3.-Relationship between the residual exchangeable $\mathrm{Mg}$ in the soil and total marketable bunch weight after a 3-year growing period.

\section{LITERATURE CITED}

1. Abruña, F., J. Vicente-Chandler, J. Figarella and S. Silva, 1976. Potassium supplying power of the major Ultisols and Oxisols of Puerto Rico. J. Agric. Univ. P. R. 60 (1): $45-60$.

2. Caro-Costas, R., F. Abruña and J. Vicente-Chandler, 1964. Response to fertilization of strip-cultivated plantains growing on a steep Latosol in the humid mountain region of Puerto Rico. J. Agric. Univ. P. R. 48 (4): 312-17.

3. Chapman, H. D. and P. F. Pratt, 1961. Methods of analysis for soils, plants and water. Univ. Calif., Div. Agric. Sci.

4. Fox, R. L., R. S. Yost, N. A. Saidy and B. T. Kang, 1985. Nutritional complexities associated with pH variables in humid tropical soils. Soil Sci. Soc. J. $49(6)$ : 1475-80.

5. Hernández-Medina, E. and M. A. Lugo-López, 1969. Effect of minor nutrient elements and magnesium upon the growth, development and yields of plantains. J. Agric. Univ. P. R. 53 (1): 33-40.

6. Irizarry, $H$. and R. Montalvo-Zapata, 1986. Conjunto tecnológico para la producción de plátanos y guineos. Publ. 97, 2nda. ed., Esta. Exp. Agric. Univ. P. R.

7. - E. Rivera and J. Rodriguez, 1988. Nutrient uptake and dry matter composition in the plant crop and first ratoon of the Grand Nain banana grown on an Ultisol. $J$. Agric. Univ. P. R. 72 (3): 337-51.

8. — E. E. Rivera, I. Beauchamp de Caloni and R. Guadalupe, 1989. Performance of elite banana (Musa acuminata, AAA) cultivars grown at four locations in Puerto Rico. J. Agric. Univ. P. R. 72 (3): 209-21. 
9. Rodríguez-García, J., E. Rivera and F. Abruña, 1985. Crop response to soil acidity factors in Ultisols and Oxisols in Puerto Rico. XIV. Plantains and bananas. J. Agric. Univ. P. R. 69 (3): 377-82.

10. Samuels, G., E. Hernández and S. Torres, 1975. Response of plantains to magnesium fertilizer in an Ultisol. J. Agric. Univ. P. R. 59 (3): 233-35.

11. Sánchez, P. A., 1974. Properties and management of soils in the tropics. John Wiley and Sons Inc., N. Y.

12. Soto, M., 1985. Bananos: Cultivo y Comercialización. LIL S.A., San José, Costa Rica.

13. Vicente-Chandler, J., F. Abruña, R. Caro-Costas, J. Figarella, S. Silva and R. W. Pearson, 1974. Intensive grassland management in the humid tropics of Puerto Rico. Bull. 233, Agric. Exp. Stn. Univ. P. R.

14. - 1985. Una nueva agricultura para Puerto Rico-Año 2,000. USDA-ARS, Agric. Exp. Stn. Univ. P. R. 